\title{
Dorota Dąbrowska
}

\section{O pamięci w eseistyce dotyczącej polskości - między esencjalizmem a konstruktywizmem}

Kategoria pamięci widziana jako komponent współczesnej refleksji nad tożsamością polską ujawnia się jako jej podstawowy składnik, konieczny punkt odniesienia dla koncepcji o różnej proweniencji ideowej. Jak pisze w książce O pojęciu tradycji Paweł Grad:

$\mathrm{Na}$ „znaczenie pamięci” powołuje się dziś zarówno prawica jak i lewica. [...] Nikt poważny nie atakuje już przeszłości wyłącznie w imię „postępu” - ci, którzy tak jeszcze czynią, uznawani są za zagubionych w czasie dziewiętnastowiecznych modernizatorów. Weszliśmy w okres modernizacji refleksyjnej i dowartościowanie „tradycji” uchodzi dziś za przejaw prawdziwego oświecenia. Kultura pamięci jest więc przejawem ducha nowoczesności pojednanej ze swoją przeszłością, jest syntezą wyłaniającą się z dialektyki oświecenia ${ }^{1}$.

Dorota Dąbrowska (ORCID: 0000-0003-4410-1930) - doktor nauk humanistycznych w zakresie literaturoznawstwa, asystent na Wydziale Nauk Humanistycznych Uniwersytetu Kardynała Stefana Wyszyńskiego w Warszawie, sekretarz redakcji czasopisma „Załącznik Kulturoznawczy”. Zainteresowania naukowe: perswazyjność kultury artystycznej, współczesne koncepcje tożsamości polskiej, przekład intersemiotyczny. Kontakt: dkdabrowska@gmail.com.

1 P. Grad, O pojęciu tradycji. Studium krytyczne kultury pamięci, Fundacja Augusta hr. Cieszkowskiego, Warszawa 2017, s. 9-10. Zacytowane zdania nie wyrażają bezpośrednio przekonań autora (który dąży do odsłonięcia „pozorności tego ponowoczesnego pojednania”), stanowią rekonstrukcję pewnego przywoływanego (i krytykowanego) przez niego punktu widzenia. 
W podobnym duchu utrzymane są uwagi Pawła Rojka, który ze stwierdzenia powszechnego charakteru odwołania do przeszłości (którego narzędziem jest pamięć) wyciąga daleko idące wnioski:

[...] przekonanie o związku tradycji i nowoczesności staje się powoli jedną z polskich „oczywistych oczywistości”. Coraz mniej jest tak naprawdę poważnych autorów i istotnych sił politycznych, które chciałyby zająć któreś ze skrajnych stanowisk w dawnym polskim sporze między modernizatorami a tradycjonalistami. Modernizatorzy powszechnie szukają dziś legitymizacji w tradycji, a tradycjonaliści chcą szczerze wspierać modernizację. I jedni, i drudzy odwołują się do przeszłości, choć podkreślają w niej odmienne wątki, wszyscy też mówią o nowoczesności, choć rozumieją ją w rozmaity sposób².

Tym śmiałym deklaracjom (reprezentującym zresztą odmienne szczegółowe rozpoznania), wieszczącym kres utrwalonej w polskiej kulturze opozycji, można przeciwstawić choćby późniejszy, bo pochodzący z roku 2017, artykuł Bartosza Jastrzębskiego, zaświadczający o żywotności podziału, który w jego tekście określony jest jako spór tradycjonalistów i progresywistów. Najistotniejszy wątek argumentacji badacza stanowi odwołanie do filozoficznych podstaw tych dwóch opozycyjnych stanowisk:

Polsko-polska wojna kulturowa [...] trwa w najlepsze, mało tego - staje się coraz to bardziej bezkompromisowa i brutalna. Tylko umysł niedoświadczony i ślizgający się po powierzchni zjawisk może ją uznać za fenomen li tylko polityczny - w istocie bowiem problem jest głębszy: chodzi tu o starcie dwóch różnych filozoficznych i moralnych światów. [...] dualizm ów leży u podstaw obecnych płomiennych debat, sporów i kłótni, które w związku z tym są sporami paradygmatów, a więc z natury rzeczy pozostają konfliktami nierozwiązywalnymi, a przez to też niekończącymi się ${ }^{3}$.

Pozostawiając na boku kwestię tego, w jakim stopniu opozycje te są aktualne, jak się zmieniają oraz rezygnując z próby precyzyjnego ich zdefiniowania, można stwierdzić, że niewątpliwie zaistniały one w polu dyskursu na temat tożsamości polskiej. Pojęcie pamięci nie stanowi, być

2 P. Rojek, Awangardowy konserwatyzm. Idea polska w późnej nowoczesności, Ośrodek Myśli Politycznej, Kraków 2016, s. 190.

3 B. Jastrzębski, Tradycjonaliści i progresywiści na kulturowej wojnie, „Teologia Polityczna”, 6 marca 2017, https://teologiapolityczna.pl/prof-bartosz-jastrzebski-radycjonalisci-i-progresisci-nakulturowej-wojnie-tpct-49- (dostęp: styczeń 2020). 
może nigdy nie stanowiło, własności jednej ze stron tego sporu, ma ono współcześnie charakter obowiązkowego składnika tożsamościowych perspektyw. Wciąż jednak koncepcje tożsamości są zróżnicowane pod kątem roli pamięci, wagi odniesienia do przeszłości, jej znaczenia dla polskości. Choć obie strony sporu interesują się i przeszłością, i współczesnością, to każda $\mathrm{z}$ nich wybiera jeden $\mathrm{z}$ tych punktów odniesienia jako kryterium wartościowania.

Postawienie pojęcia pamięci w centrum rozważań nad współczesnymi koncepcjami tożsamości polskiej pozwala uprzytomnić sobie ich wewnętrzne zróżnicowanie, daje możliwość wytyczenia podziału na ujęcia dowartościowujące rolę pamięci i te, które ją marginalizują. Gdyby zapytać o filozoficzne podstawy tych dwóch typów koncepcji polskości, można by odwołać się do pojęć esencjalizmu i konstruktywizmu, funkcjonujących w refleksji nad tożsamością jako opozycyjne paradygmaty kulturowe ${ }^{5}$. Najbardziej powszechne rozumienie esencjalizmu, określające tożsamość jako niezmienną lub nawet biologicznie zdeterminowaną ${ }^{6}$ jest współcześnie traktowane jako archaizm; można powiedzieć, że esencjalizm w tej „twardej” postaci odszedł wraz z pojęciem charakteru narodowego (które uległo zanegowaniu ze względu na element deterministyczny i nieuwzględnienie aspektu jednostkowej podmiotowości) ${ }^{7}$. Można jednak

4 Por. uwagi Marcina Króla na temat stosunku środowisk liberalnych do przeszłości: „Występują więc podziały między tymi, którzy dostrzegają szansę na poszukiwanie źródeł czy podstaw dla obecnej polskości w przeszłości, w jej archiwum, a tymi, którzy sądzą, że polskość w zasadzie nie jest do niczego potrzebna. [...] Takie stanowisko zajmują radykalnie liberalne środowiska, dla których przeszłość [...] jest tylko obciążeniem, a żadna jej interpretacja, co wiedzą z góry, nie zmieni ich poglądu. Tożsamość jednostki i tożsamość zbiorowa powinna być budowana wyłącznie w oparciu o to, co się dzieje teraz.” M. Król, Patriotyzm przyszłości, Rosner \& Wspólnicy, Warszawa 2004, s. 115.

5 Por. Z. Bauman, O tarapatach tożsamości w ciasnym świecie, w: W. Kalaga (red.), Dylematy wielokulturowości, Universitas, Kraków 2004; A. Giddens, Nowoczesność i tożsamość. "Ja” i spoteczeństwo w epoce późnej nowoczesności, tłum. A. Szulżycka, Wydawnictwo Naukowe PWN, Warszawa 2001, s. 5-6; 76-77.

6 Por. A. Wiktorska-Święcka, Wyznaczanie granic i konstruowanie tożsamości Europy, w: A. Pacześniak, M. Klimowicz (red.), Procesy integracyjne i dezintegracyjne w Europie. Podręcznik akademicki, OTO, Wrocław 2014, s. 30.

7 Por. Z. Bokszański, Tożsamości zbiorowe, Wydawnictwo Naukowe PWN, Warszawa 2005, s. $105-106$. 
odwołać się do innego rozumienia esencjalizmu, opartego na przekonaniu o istnieniu prawdy na temat tożsamości, wyobrażeniu o jej właściwym, pożądanym kształcie. Ten rodzaj esencjalizmu definiuje tożsamość jako coś, co należy odkryć, a zatem coś, co istnieje obiektywnie. Przeciwstawione tej perspektywie ujęcia konstruktywistyczne to takie, które opierają się na przekonaniu o konieczności wyswobodzenia tożsamości z wszelkich rygorów i zobowiązań wobec przeszłości oraz dopuszczenia do jej swobodnego kreowania. Zróżnicowanie to oddaje trafnie fragment artykułu Małgorzaty Dziekanowskiej, która ujmuje tę opozycję przez analogię do relacji między losem a wyborem:

O ile nie budzi sprzeciwu uznanie tożsamości subiektywnej, odnoszącej się przede wszystkim do samowiedzy jednostek i zbiorowości, o tyle uznanie jej obiektywnego charakteru jako czegoś, co istnieje w sposób obiektywny i zewnętrzny, dostępny obserwacji, nie jest już tak oczywiste. Jeżeli przyjmiemy, że tożsamość nie jest jedynie prostą reakcją na sytuację zewnętrzną, ale efektem jej twórczego interpretowania, to trudno będzie podtrzymać tezę o obiektywnym charakterze tożsamości. Zwłaszcza że w czasach płynnej nowoczesności, rosnącej heterogeniczności społeczeństw, jednostki ulegają wielu, często sprzecznym, wpływom. Rozziew między tożsamością a sytuacją zewnętrzną jest obecnie większy niż kiedykolwiek. Tożsamość musi być zatem konstruowana i negocjowana. W coraz większym stopniu staje się wyborem niż losem ${ }^{8}$.

Odnosząc te pojęcia do dwojakiego rodzaju koncepcji polskości, można by intuicyjnie przypisać narracjom dowartościowującym pamięć bliskie związki z esencjalizmem, zaś tym, które stawiają w centrum imperatyw fortunności wobec współczesnej rzeczywistości - sympatyzowanie z konstruktywizmem.

W niniejszym artykule chciałabym wykazać na przykładzie drobnego wycinka interesującego mnie materiału eseistycznego, że faktycznie relacja ta kształtuje się inaczej - to znaczy, że elementy tych dwóch nurtów ideowych przenikają się w obrębie różnorodnych koncepcji polskości, a niekiedy dzieje się to w sposób przeczący przed chwilą wyrażonej intuicji. Pokazanie wewnętrznej złożoności analizowanych tu wypowiedzi

8 M. Dziekanowska, Tożsamość spoteczna a globalizacja, „Zeszyty Naukowe Uniwersytetu Szczecińskiego" 2018, nr 18 (517), s. 34. 
służyć ma podkreśleniu, że funkcjonujące w powszechnej opinii przekonania na temat tożsamości poszczególnych grup światopoglądowych, kierunków intelektualnych stanowią wyraz uproszczenia i powinny być weryfikowane przez dokładniejszy ogląd tych dyskursywnych ścieżek.

Interesujące mnie zjawisko chciałabym pokazać na przykładzie dwóch publikacji - Awangardowego konserwatyzmu Pawła Rojka' i szkicu Polska: wspólnota fantazmatyczna Agaty Bielik-Robson ${ }^{10}$. Gatunkowa przynależność analizowanych przeze mnie tekstów (ich eseistyczny charakter) czyni je wypowiedziami nieobarczonymi rygorem filozoficznej spójności, z tego właśnie względu pozwalają się one traktować równocześnie jako spontaniczne odzwierciedlenia pewnych tendencji myślowych - w większym stopniu niż w wypadku innych gatunków wypowiedzi. Niniejszy artykuł nie stawia sobie za cel szczegółowego omówienia wskazanych publikacji, a jedynie ich interpretację w kontekście wskazanej w tytule pary pojęć widzianych w perspektywie znaczenia pamięci. Nie jest również moją intencją eksploracja całego bogatego pola problemowego, jakie otwiera sformułowanie „o pamięci w eseistyce dotyczącej polskości” - ograniczam się do refleksji nad jednym zagadnieniem rysującym się w tym obszarze.

Potraktujmy Awangardowy konserwatyzm Pawła Rojka jako przykład wypowiedzi dowartościowującej pamięć, zawarta w nim koncepcja polskości ma bowiem polegać na kultywowaniu idei polskiej wydobytej z przeszłości. Książkę tę potraktować można jako tekst, w którym szczególnie wyraziście przenikają się dwa przeciwstawne żywioły (esencjalizm i konstruktywizm) w obrębie jednej wypowiedzi, jednej postawy (co sugeruje już sam tytuł). Rojek nie kryje ejdetycznego ${ }^{11}$, postulatywnego charakteru swojego projektu. Kluczowa myśl publikacji zawiera się w idei zakładającej konieczność rekonstrukcji polskiej tożsamości po komunistycznym wykorzenieniu. Warto podkreślić, że rekonstrukcja ta nie ma u swoich podstaw dążenia do odtworzenia idei polskiej w niezmienionym kształcie, a intencję jej reinterpretacji (autor posługuje się określeniem „twórcza selekcja”). Cel tego przedsięwzięcia związany jest z ambicją

9 P. Rojek, Awangardowy konserwatyzm.

10 A. Bielik-Robson, Polska: wspólnota fantazmatyczna, w: Kim są Polacy?, Agora, Warszawa 2013.

11 Por. K. Mazur, Polska ejdetyczna, „Pressje” 2010, teka 22/23. 
millenarystyczną, we wstępie czytamy: „Polska idea może więc nie tylko wskrzesić Polskę, ale i zbawić świat" ${ }^{\text {"2 }}$. Polskość nie jest traktowana wyłącznie jako dziedzictwo godne podtrzymania, ale również jako narzędzie zmiany o charakterze ponadnarodowym. $Z$ podobnym rozmachem mamy do czynienia $\mathrm{w}$ koncepcji polskości ejdetycznej sformułowanej przez Krzysztofa Mazura, opartej na idei wolności ${ }^{13}$. Jej kluczowe znaczenie dla polskiej kultury częściowo zostaje przez autora wywiedzione z polskiej historii, równocześnie jednak autor otwarcie wskazuje na liczne korzyści płynące $\mathrm{z}$ wyboru tej wartości jako podstawy kulturowego paradygmatu - polska wolność, będąca połączeniem liberum veto i liberum servio, ma szansę zjednoczyć skłócone ze sobą obozy polityczne, pozwala się traktować jako cel uniwersalny, niezależny od światopoglądu, a nawet kulturowego, czy też narodowego, wyposażenia.

Wracając do Awangardowego konserwatyzmu - projekt naszkicowany przez Rojka jest esencjalistyczny jedynie w dość powierzchownym sensie, a mianowicie na płaszczyźnie związku wartości wypełniających postulowaną przezeń ideę polską z esencjalistycznym paradygmatem. Treść polskości stanowi dla Rojka przede wszystkim chrześcijaństwo, a zatem światopogląd esencjalistycznie zorientowany. Drugi niuans świadczący o związkach koncepcji z esencjalizmem to nazwanie przez autora idei polskiej „niezniszczalną”. W Awangardowym konserwatyzmie dostrzec można dwa aspekty projektu świadczące o przechylaniu się zawartej w książce perspektywy ku konstruktywizmowi - po pierwsze w rozważaniach nad tożsamością polską autor nie uwzględnia realności przemian dokonanych w PRL-u, nie zadaje pytania o to ,jaka polskość rzeczywiście obecnie JEST - w wyniku tych przemian?", nie podejmuje kwestii stanu świadomości Polaków, a koncentruje się na działaniu rekonstrukcyjno-postulatywnym. Po drugie - proces rekonstrukcji, dokonana selekcja historycznych punktów oparcia i dążenie do promocji tej interpretacji polskości stanowią zabiegi jawnie konstruktywistyczne. Konstruktywistyczny jest również w pewnym sensie sam ejdetyczny tryb definiowania tożsamości - oczywiście idee w nim lokowane odgrywają rolę w polskiej historii, zostają z niej 
wydobyte, równocześnie jednak bardzo wyraźne jest to, że ich ekspozycja umotywowana jest intencją osiągnięcia pewnego celu, jak na przykład we wspomnianej już koncepcji polskości ejdetycznej Mazura (polska wolność stanowi motyw obecny w wielu ważnych momentach dziejowych, równocześnie jednak nadaje się jej rolę kluczowego pojęcia ze względu na płynące z tego korzyści).

Interesujących obserwacji na temat związków Awangardowego konserwatyzmu z esencjalizmem i konstruktywizmem dostarczają zwierzenia autora wyrażone w ramach dyskusji opublikowanej na łamach "Pressji”. Rojek zdradza osobisty charakter sformułowanego projektu, traktuje go jako narzędzie ekspresji swojego doświadczenia, ale również doświadczenia całego pokolenia:

Ktoś spytał mnie o to, dla kogo napisałem tę książkę. Bardzo mnie zaskoczyło to pytanie, bo rzecz jasna pisałem ją przede wszystkim dla siebie. Tak jak mówisz, jest to próba zrozumienia i uporządkowania dla siebie samego rozmaitych wątków ideowych i historycznych. Nie sądzę jednak, by w jakiś sposób unieważniało to jej tezy. Wręcz przeciwnie. Mam bowiem nadzieję, że jest ona czymś więcej niż tylko opowieścią o mnie samym. Chciałem, by wyrażała jakieś szersze doświadczenie pewnego środowiska, którego jestem członkiem, może nawet pokolenia. Przecież każdy autor funkcjonuje w jakichś wspólnotach, w jakimś określonym miejscu i w konkretnym czasie. Jesteśmy tworzeni przez religię, naród, sztukę, przyjaciól, książki. Naszym zadaniem jest intelektualne ogarnięcie swojej sytuacji, opowiedzenie własnego doświadczenia, także w imieniu innych, którzy znajdują się w podobnych miejscach. [...] Umniejszyłbym nawet podmiotową rolę autora na rzecz wizji bycia funkcją całego otoczenia, w jakie jestem wpisany.

Choć wytwarzana przez autora idea polska stanowi rezultat świadomie zaprojektowanych zabiegów, jest równocześnie ściśle zakorzeniona w doświadczeniu, które postrzega autor w sposób zaskakująco jednorodny - sygnalizuje, że sieć kontekstów, jakie kształtują jego osobistą historię, kulturowe podłoże pozwala się traktować jako wspólna dla całego pokolenia. Wbrew konstatacjom potwierdzającym tezę o niemożności myślenia w kategoriach ciągłości oraz opierania tożsamości na etosie ${ }^{14}$, autor zdaje się sugerować, że można mówić o pewnym uogólnionym doświadczeniu „współczesnego Polaka”. 
Drugi tekst - esej Agaty Bielik-Robson Polska: wspólnota fantazmatyczna traktuję jako przykład narracji w mniejszym stopniu akcentującej rolę pamięci, wręcz nakłaniającej do swego rodzaju zapomnienia (mimo pozornej wagi odwołania do przeszłości). Tekst ten pokazuje tożsamość polską jako niewłaściwą, zagubioną, bo - tonącą w mitach. Autorka stawia w centrum kategorię nowoczesności, nadaje jej rolę narzędzia weryfikacji fortunności tożsamości. Słowo nowoczesność odsyła oczywiście do pewnego paradygmatu ideowego, ale funkcjonuje tu przede wszystkim jako synonim współczesności, przez co pozwala określić ideową tożsamość eseju jako „przyszłościową”, powiązaną z progresywizmem. Tożsamość właściwa to - wedle autorki - ta, która jest uzgodniona z nowoczesnością poprzez pracę nad historią, jej reinterpretację. Bielik-Robson występuje przeciwko Polakom tkwiącym przy esencji (mówi o niezmordowanym obozie patriotycznym trwającym uparcie na pozycjach czystej esencji), sama jednak przeciwstawia im „realną tożsamość”. Zaprzecza więc możliwości posługiwania się mitami, negatywnie wartościuje fantazję, jaką jest „życie przeszłością". Kwestionując adekwatność mitów i fantazji, autorka stawia tym samym tamę zabiegom konstrukcyjnym, wyrażając przez to przekonanie, że istnieje rzeczywistość poza konstrukcją, a zatem, że daje się pomyśleć coś takiego jak polskość prawdziwsza, niezachwaszczona archaicznymi narracjami. Sąd ten naznaczony jest właściwą skrajnym formom esencjalizmu naiwnością, lekceważy dyskursywny charakter tożsamości, prawo jej użytkowników do negocjowania jej kształtu - przy użyciu swobodnie wybieranych narzędzi.

Normatywny charakter perspektywy wpisanej w tekst Bielik-Robson ujawnia się w początkowych fragmentach eseju, w których autorka odwołuje się do koncepcji Charlesa Taylora. Wyraźnie przeciwstawia sobie Taylorowski model człowieka jako selfinterpretating animal i zjawisko autofantazjowania. Tożsamość nie może być, według autorki, czymś wymyślonym, nie może również opierać się nad podświadomej pracy pamięci ani pamięciowym konstrukcie - musi być rezultatem świadomej pracy nad przeszłością. W dalszej części tekstu odnoszącej się do konkretnych realiów, czyli rzeczywistości polskiej, Bielik-Robson postuluje jednak odrzucenie reliktów przeszłości na rzecz dążenia do fortunności wobec współczesności. Deklaratywnie jest przeciwko esencjalizmowi, ale praktycznie sama odwo- 
łuje się do idei tożsamości jako przepracowywania historii, zobowiązania, a zatem do normatywnego rozumienia tożsamości jako czegoś co prawda zmiennego w czasie, ale równocześnie - na drodze stałego przypisania do ścisłej relacji z warunkami zewnętrznymi - z góry określonego, koniecznego do odkrywania. Stanowisko to sprzeczne jest również z konstruktywistycznym dowartościowaniem podmiotowości, założeniem, że tożsamość stanowi pole negocjacji wolnych podmiotów współtworzących swój los.

Autorka zakłada, że „tożsamość polska odporna na próby przepracowania" to czysty archaizm. Jako jedyne kryterium jej fortunności uznaje jej adekwatność wobec nowoczesności. Choć jest to niewątpliwie ważne kryterium, nie zmienia to jednak faktu, że nadanie mu charakteru jedynego, wyłącznego narzędzia oceny stanowi mocny gest o charakterze normatywnym. Mówiąc „tożsamość polska jest do niczego, bo nijak się ma do współczesności" autorka dokonuje arbitralnej oceny. Spojrzenie na tę ocenę w perspektywie pary pojęć esencjalizm - konstruktywizm rzuca na tę konstatację nowe światło. Gdyby szukać najsilniej współgrającej z „duchem czasów” tożsamościowej doktryny filozoficznej to byłby nią, jak sądzę, konstruktywizm ${ }^{15}$ - ten zaś nie nakłada zobowiązań, nie obwarowuje zakazami, a daje możliwość swobodnego wybierania, kreowania swojego $\operatorname{losu}^{16}$. Bielik-Robson mówiąc, że Polacy nie powinni kultywować wartości

15 Por. M. Wendland, Konstruktywizm komunikacyjny, Wydawnictwo Naukowe Instytutu Filozofii Uniwersytetu im. Adama Mickiewicza, Poznań 2011, s. 53-61; E. T. Hall, Bezgłośny język, przekł. R. Zimand, A. Skarbińska, Państwowy Instytut Wydawniczy, Warszawa 1987, s. 124; A. Zybertowicz, Przemoc i poznanie: studium z nie-klasycznej socjologii wiedzy, Uniwersytet Mikołaja Kopernika, Toruń 1995, s. 17. Książka Zybertowicza stanowi, nawiasem mówiąc, interesujący przykład przenikania się konstruktywizmu i esencjalizmu (jako przyjmowanych przez podmiot perspektyw) w obrębie jednego wywodu naukowego; Autor, deklarując aprobatywny stosunek do konstruktywizmu (s. 18) oraz intencję przeciwstawienia się obiektywistycznym modelom poznania (s. 16), kończy swój wywód stwierdzeniami o jednoznacznie esencjalistycznej wymowie: „Jeśli tak, to trzeba być bardzo ostrożnym. Z podobną skutecznością można przyswoić sobie prawdę, jak i zainfekować się kłamstwem, fikcją i szaleństwem" (s. 375).

Por. uwagi Katarzyny Skrzypczak: „Paradygmat konstruktywistyczny zakłada, że tożsamość jest ściśle powiązana z zagadnieniem dialogu. Zdaniem Morina specyfiką kultury europejskiej jest właśnie ciągłość i intensywność dialogu. Europa jest zarazem twórcą i rezultatem rozmaitych interakcji pomiędzy opozycyjnymi wartościami, postawami i kategoriami, takimi jak racjonalność i religia, partykularyzm i uniwersalizm, mit i krytyczna refleksja, jednostka i wspólnota”; K. Skrzypczak, Jaka tożsamość kulturowa dla dzisiejszej Europy?, „Refleksje” 2010, nr 1, s. 216. 
wynikających z tradycji (o ile nie są one zgodne z poetyką współczesności, a jak wiadomo często nie są) przemawia więc przeciwko wolności samostanowienia, kreowania tożsamości, a również ustawia polskość na pozycji peryferyjnej wobec Zachodu (czyli tego, który wyznacza trendy). Jej argumentacja opiera się paradoksalnie na narracji quasi-esencjalistycznej, stoi za nią przekonanie, że istnieje polskość właściwa, ta, która wynika z właściwego odczytania znaków czasu.

Normatywny i quasi-esencjalistyczny ton eseju Bielik-Robson daje do myślenia w kontekście innych tekstów zawartych w książce Kim sq Polacy?, na przykład tekstu Przemysława Czaplińskiego, który pokazuje, że nie sposób powiedzieć, kim są Polacy, można jedynie śledzić sposoby, w jakie modelują oni swoją tożsamość. Autor dochodzi do podobnych wniosków, jak Bielik-Robson, jednak nadaje im inne znaczenie:

Kim są Polacy? Potrafię odpowiedzieć na to pytanie tylko w jeden sposób: są społecznością sfingowaną. Nie znaczy to: sfałszowaną, nieprawdziwą, fikcyjną. Znaczy: społecznością, która nieprzerwanie samą siebie wymyśla, społecznością sklejaną przez kolejne mity, istniejącą w narracjach. Zbiorowość układa o sobie opowieści, a poprzez owe opowieści wytwarza możliwe więzi; ich pojemność, zdolność do wkluczania i wykluczania, zdecyduje o tym, jak wielu zechce o sobie mówić i myśleć „My, Polacy”. Ten akt dopisania siebie do wspólnoty wymaga właśnie fingowania ${ }^{17}$.

Diagnoza Czaplińskiego jest podobna to sformułowanej przez Bielik-Robson, ale tu nie ma charakteru oskarżenia, nie staje się punktem wyjścia dla postulatu zmiany - jest jedynie stwierdzeniem faktu, które pozwala się utożsamić z opisem uniwersalnego mechanizmu wytwarzania tożsamości, jest więc wyrazem zgody na owo „wymyślanie”, potwierdzeniem fortunności (lub nieuchronności) konstruktywistycznego paradygmatu.

W podobnym duchu utrzymany jest opis wydawniczy umieszczony na okładce książki:

Po ponad dwudziestu latach niepodległości, tworzenia nowego ustroju i wolnego rynku potrzebujemy namysłu nad tym, jacy jesteśmy i co dalej. Polacy - często głęboko podzieleni - muszą ze sobą rozmawiać. To dlatego powstała ta książka - zbiór głosów wybitnych intelektualistów. Czytajmy, dyskutujmy, spierajmy się. Wymyślmy siebie na nowo ${ }^{18}$. 
Zakończenie opisu słowami „wymyślmy siebie na nowo” jednoznacznie wiąże się z myśleniem konstruktywistycznym. Bielik-Robson zdaje się nie brać pod uwagę tego, że przyjmowanie pozycji odmiennej od preferowanej przez nią nie musi oznaczać ślepego trwania przy znanym, ale może wynikać z wolnego wyboru. Tak we współczesnej Polsce żywotność pewnych wartości nie musi wynikać z kulturowego marazmu, a może być kwestią świadomych zabiegów kreacyjnych, wyborów identyfikacyjnych.

Quasi-esencjalistyczny sposób myślenia o tożsamości jako wyzwaniu polegającym na właściwym przepracowaniu dziejów pojawia się również w najnowszej książce Andrzeja Mencwela:

Podobnie jednak jak dojrzałość osoby poszczególnej, dojrzałość narodu związana jest z osiągnięciem właściwej sobie tożsamości. Tożsamość taka powinna być możliwie spójna, to znaczy odpowiadać wyzwaniom dziejowym i minimalizować wewnętrzne napięcia tak, aby działały one jako czynniki rozwojowe, a nie cofające. [...] Słowem, w wielogłosowej społecznie tożsamości narodowej chodzi o osiągnięcie harmonii, a nie o głuszenie kakofonią. Sądzę otóż, że polska tożsamość współczesna jest wyraźnie niespójna, jej wewnętrzne napięcia źle się maksymalizują, co grozi rozstrojem wewnętrznym i bezwładem zewnętrznym, i to właśnie wtedy, kiedy jak może nigdy dotąd mamy możliwości rozwoju wszechstronnie twórczego, wyzyskującego korzystne położenie zewnętrzne oraz uwolnienie sił wewnętrznych. Stoimy na progu dojrzałości dziejowej, ale nie ma gwarancji, że ją osiągniemy ${ }^{19}$.

Tożsamości nie można więc sobie wymyślić, należy dążyć do odkrycia jej właściwego, spójnego charakteru („tożsamość [...] jest tworem głębokiego, wielowarstwowego procesu dziejowego"20). Równocześnie jednak we wstępie do książki, Mencwel odróżnia spuściznę od tradycji, tę drugą określając jako „to, co z pokładów spuścizny celowo wydobywamy i afirmujemy jako wartość godną rozmyślnej kontynuacji, więc trwałą"21. Tworzenie tożsamości opartej na tradycji stanowi więc działanie o charakterze konstruktywistycznym, postulat „przepracowywania historii” zawsze wiąże się z wyborem, wartościowaniem, stanowi interpretację przeszłości. Normatywny ton koncepcji tożsamości wpisanych w teksty Bielik-Robson

19 A. Mencwel, Przedwiośnie czy potop 2. Nowe krytyki postaw polskich, Wydawnictwo Krytyki Politycznej, Warszawa 2019, s. 82-83.

20 Ibidem, s. 80.

21 Ibidem, s. 12. 
i Mencwela nie tylko zawiera elementy esencjalizmu, ale pozwala się interpretować jako sprzeczny z liberalną perspektywą rozumienia polskości. Dobrze „oświetlają” te kwestie stwierdzenia sformułowane przez Marcina Króla w książce Patriotyzm przyszłości:

Rzecz bowiem w tym, że liberalny patriotyzm [...] zakłada, że nie ma permanentnych sporów, tylko permanentne współżycie poglądów na polskość, wyobrażeń polskości, które różnią się od siebie zasadniczo. Nie tylko nikt, jak to się kolokwialnie mówi, nie ma patentu na polskość, ale nikt go nigdy mieć nie może. Taka sytuacja jest wykluczona w czasach zerwania ciągłości i w czasach, kiedy przeszłość już nie jest dla nas źródłem dyrektyw, jak należy czuć, myśleć i postępować. Możemy krytykować cudze poglądy, możemy uważać, że są one naganne moralnie czy intelektualnie, ale nie możemy ani zabronić ich głoszenia, ani wykluczać ze wspólnoty narodowej tych, którzy je głoszą ${ }^{22}$.

W kontekście znaczenia pojęcia pamięci dla zróżnicowania koncepcji polskości zasadne jest odwołanie do innego eseju Bielik-Robson poświęconego pamięci zatytułowanego Pamięć, czyli farmakon. Tekst ten również odwołuje się do idei „przepracowywania dziejów”, jednak jest tu ono rozumiane jako dążące do uznania własnej peryferyjności wobec Zachodu i opiera się na nietzcheańskiej formule pamiętania negatywnego - pamiętamy po to, by nie powtórzyć błędów historii. Właściwy rodzaj pamiętania (przeciwstawiony błędnemu) okazuje się być w istocie zapomnieniem:

W obu tych tekstach, i Nietzschego, i Freuda, dochodzi do głosu pewien paradoks: dobre, odpowiednie pamiętanie okazuje się częściowo zapomnieniem, gdzie zapomnienie, ta Nietzscheańska aktive Vergessenheit, to nade wszystkim zdolność do nabrania dystansu do tego, co było, jako właśnie przeszłości, czyli czegoś, co już nie istnieje. Pamięć właściwa zatem korzystałaby dialektycznie z mocy zapominania, która oddala to, co przeszłe, od żywego spektrum teraźniejszości, nie pozwalając tym samym, by widma przeszłych zdarzeń nakładały się na czas przeżywany tu i teraz ${ }^{23}$.

Autorka określa traktowanie wciąż żywej przeszłości jako patologię. Również w tym tekście wybrzmiewa esencjalistyczne przekonanie o istnieniu właściwej tożsamości motywujące do zakwestionowania praktyk pamięciowych dowartościowujących historię. 
Opierając się na przywołanych przykładach, można by uznać, że dzisiejszy konserwatyzm jest bardziej konstruktywistyczny niż myśl modernizatorska, dystansująca się wobec polskiej tradycji w imię postępu i nowoczesności oraz odwołująca się do arbitralnej wizji przeszłości ukazywanej jako jedyna słuszna jej interpretacja. Oczywiście tego rodzaju stwierdzenie potraktować trzeba jako uogólnienie, dla którego uprawomocnienia należałoby sięgnąć po dziesiątki innych przykładów. Obydwa analizowane tu teksty mają charakter normatywny - jeden z nich (książka Rojka) zupełnie otwarcie obnaża konstruktywistyczny szkielet poetyki proklamowanego projektu, drugi - esej Bielik-Robson - jest normatywny w sposób bardziej dyskretny, poprzez dyskredytację konstruktywistycznych zabiegów w wyniku odwołania do ustanowionej „normalności”.

Przeprowadzone rozważania pozwalają zauważyć istnienie dwojakiego rodzaju odniesień do esencjalizmu i konstruktywizmu - dana koncepcja może opierać się na normatywnym, esencjalnym przekonaniu o istnieniu idei polskiej jako czegoś nieprzygodnego, wynikającego z dziejów, zobowiązującego do podtrzymania pamięci, a równocześnie sięgać po narzędzia z zakresu konstruktywizmu, inna zaś sugerować ścisły związek ze współczesnymi ideami, równocześnie posiłkując się taktyką opartą na kategoriach „tradycyjnych” lub wręcz zdyskredytowanych przez współczesnośćc $^{24}$. Zastosowanie kategorii esencjalizmu i konstruktywizmu wobec esejów dotyczących tożsamości polskiej wzbogaca perspektywę ich interpretacji oraz prowokuje do ponowienia pytania na temat specyfiki ideowej opozycyjnych nurtów kulturowych zaangażowanych w refleksję nad polskością.

Uprzytomnienie sobie występowania tego zjawiska skłania do namysłu nad jego przyczynami. Intencja udzielenia odpowiedzi na pytanie,

24 Por. uwagi M. Gierycza: „Carole S. Vance pośrednio dowodzi, że konstruktywiści cierpią na syndrom pana Jourdaina: „niektórzy używają słów »społeczne tworzenie rzeczywistości«, podczas gdy ramy analityczne, z których korzystają, zawierają wiele elementów esencjalistycznych, z czego sami sobie nie zdają sprawy (Vance 2007: s. 16)”. W istocie jednak nie chodzi o "niektórych”, a wszystkich. Bowiem, jak szczerze przyznaje, problemem są „pozostałości esencjalizmu w każdym z nas"; M. Gierycz, Blaski i cienie konstruktywizmu w studiach europejskich, „Przegląd Europejski” 2016, nr 2 (40), s. 140. 
dlaczego te dwojakiego rodzaju kierunki myślenia się przeplatają, wykracza poza założenia niniejszego szkicu. Niewątpliwie esencjalizm stanowi paradygmat ideowy bliski potocznemu myśleniu, narzucający się automatycznie. Zybertowicz pisze o nim (posługując się synonimicznym terminem obiektywizm):

[...] wydaje się być zgodny ze zdrowym rozsądkiem, całkiem przekonywający dla osób należących do nowożytnej kultury Zachodu i podejmujących namysł nad swym poznawaniem świata. Ludzie wychowani w tej kulturze wprowadzani są [...] w świat zastany, mający już gotową, kulturowo ukształtowaną postać. Są socjalizowani w taki sposób, iż uzyskują przekonanie o możliwości kontaktu z będącymi na zewnątrz, istotnie od nich innymi przedmiotami i ludźmi ${ }^{25}$.

Wiara w istnienie świata niezależnego od aktów poznawczych jest głęboko zakorzeniona w powszechnej świadomości, może więc dochodzić do głosu niezależnie od (sprzecznych wobec niej) intelektualnych wyborów. Pytając zaś o to, dlaczego współcześni tradycjonaliści odżegnują się od narracji opartej na dążeniu do zachowania ciągłości i zwracają się ku jawnemu kreacjonizmowi, można dojść do wniosku, że gest ten wyraża intencję podporządkowania się realiom współczesności lub też jej „przezwyciężenia" przy pomocy jej własnych narzędzi. Niewątpliwie jednak problem ten jest bardziej złożony i wymaga uważniejszego oglądu.

\section{Bibliografia}

Bielik-Robson A., Pamięć, czyli farmakon, „Teksty Drugie” 2016, nr 6, s. 68-78. Bielik-Robson A., Polska: wspólnota fantazmatyczna, w: Kim sa Polacy?, Agora, Warszawa 2013.

Bokszański Z., Tożsamości zbiorowe, Wydawnictwo Naukowe PWN, Warszawa 2005.

Bauman Z., O tarapatach tożsamości w ciasnym świecie, w: W. Kalaga (red.), Dylematy wielokulturowości, Universitas, Kraków 2004.

Czapliński P., Horror polonicus, w: Kim sq Polacy?, Agora, Warszawa 2013.

Dziekanowska M., Tożsamość społeczna a globalizacja, „Zeszyty Naukowe Uniwersytetu Szczecińskiego" 2018, nr 18 (517), s. 33-48.

25 A. Zybertowicz, Przemoc i poznanie..., s. 82. 
Giddens A., Nowoczesność i tożsamość. „Ja” $i$ społeczeństwo w epoce późnej nowoczesności, tłum. A. Szulżycka, Wydawnictwo Naukowe PWN, Warszawa 2001.

Gierycz M., Blaski i cienie konstruktywizmu w studiach europejskich, „Przegląd Europejski” 2016, nr 2 (40), s. 138-145.

Grad P., O pojęciu tradycji. Studium krytyczne kultury pamięci, Fundacja Augusta hr. Cieszkowskiego, Warszawa 2017.

Hall E.T., Bezgłośny język, przeł. R. Zimand, A. Skarbińska, Państwowy Instytut Wydawniczy, Warszawa 1987.

Jastrzębski B., Tradycjonaliści i progresywiści na kulturowej wojnie, „Teologia Polityczna" 6 marca.2017 https://teologiapolityczna.pl/prof-bartosz-jastrzebski-radycjonalisci-i-progresisci-na-kulturowej-wojnie-tpct-49-.

Kaszczyszyn P., Wielo-Polak, „Pressje” 2018, teka 55.

Król M., Patriotyzm przyszłości, Rosner \& Wspólnicy, Warszawa 2004.

Mazur K., Polska ejdetyczna, „Pressje” 2010, teka 22/23.

Mencwel A., Przedwiośnie czy potop 2. Nowe krytyki postaw polskich, Wydawnictwo Krytyki Politycznej, Warszawa 2019.

Rojek P., Awangardowy konserwatyzm. Idea polska w późnej nowoczesności, Ośrodek Myśli Politycznej, Kraków 2016.

Skrzypczak K., Jaka tożsamość kulturowa dla dzisiejszej Europy?, „Refleksje” 2010, nr 1, s. 203-218.

Wendland M., Konstruktywizm komunikacyjny, Wydawnictwo Naukowe Instytutu Filozofii Uniwrsytetu im. Adama Mickiewicza, Poznań 2011.

Wiktorska-Święcka A., Wyznaczanie granic i konstruowanie tożsamości Europy, w: A. Pacześniak, M. Klimowicz (red.), Procesy integracyjne i dezintegracyjne w Europie. Podręcznik akademicki, OTO, Wrocław 2014.

Zybertowicz A., Przemoc i poznanie: studium z nie-klasycznej socjologii wiedzy, Uniwersytet Mikołaja Kopernika, Torun 1995.

\section{On Memory in Essays on Polishness: Between Essentialism and Constructivism}

This article contains considerations on the diversity of essays on Polish issues, resulting from the diverse role of memory in individual concepts of national identity. The purpose of this article is to reflect on the relationship between the texts that can be described as traditionalist and modernising and essentialist and constructivist orientations. It contains the analysis of 
primarily two publications: 'Awangardowy konserwatyzm' [Avant-garde Conservatism] by Paweł Rojek and 'Polska: wspólnota fantazmatyczna' [Poland: A Phantasmatic Community] by Agata Bielik-Robson. These essays can be treated as the representative examples of complex ideological relationships occurring in considerations on Polishness.

\section{Keywords:}

MEMORY, CONSTRUCTIVISM, ESSENTIALISM, POLISHNESS. 